\title{
THE PSYCHOSOCIAL ANTECEDENTS OF THE ACCOUNTING DIGITAL TRANSFORMATION OF THE COMPANIES: A MODEL PROPOSAL IN TERMS OF THE TECHNOLOGY ACCEPTANCE THEORY
}

\author{
Nevzat GÜNGÖR ${ }^{1}$ \\ Cem Güney ÖZVEREN²
}

Selçuk YEKE

Citation/@: Güngör, N., Özveren, C.G., and Yeke S. (2020). The psychosocial antecedents of the accounting digital transformation of the companies: a model proposal in terms of the technology acceptance theory. Hitit University Journal of Social Sciences Institute, 13(1), 36-55. doi: 10.17218.hititsosbil. 740045

Abstract: This study was carried out to present a conceptual model about accounting digital transformation. Literature was deeply reviewed to determine relationships within conceptual model. The foundation of accounting digital transformation was based on technology acceptance model. In this direction, organizational, social and individual factors influencing technology acceptance through perceived usefulness of technology and perceived ease of use technology were formed within the conceptual model. Effects of attitude towards technology on intention to use technology and actual technology usage were examined. Behavioral and managerial antecedents of attitude towards technology and actual technology usage were handled within the conceptual model. Furthermore, new technologies in accounting were researched to realize from which area is begun to accounting digital transformation. As a result, it was purposed to present a conceptual model for companies that try to begin accounting digital transformation.

Keywords: Digital Transformation, Technology Acceptance Model, Emerging Technologies, Psychosocial Antecedents, Accounting Profession

Muhasebe Alanında Şirketlerin Dijital Dönüşümünün Psikososyal Öncülleri: Teknoloji Kabul Teorisi Üzerine Bir Model Önerisi

Atıf/C: Güngör, N., Özveren, C.G., and Yeke S. (2020). Muhasebe alanında şirketlerin dijital dönüşümünün psikososyal öncülleri: teknoloji kabul teorisi üzerine bir model önerisi. Hitit University Journal of Social Sciences Institute, 13(1), 36-55. doi: 10.17218.hititsosbil.740045

Özet: Bu çalışma muhasebe alanında dijital dönüşüme yönelik kavramsal bir model ortaya koyabilmek için gerçekleştirilmiştir. Model kapsamında yer alan ilişkileri belirlemek üzere derinlemesine literatür taraması yapılmıştır. Muhasebe alanına yönelik dijital dönüşüm Teknoloji Kabul Modeli'ne dayanarak açıklanmaktadır. Model kapsamında algılanan fayda ve algılanan kullanım kolaylığından oluşan Teknoloji Kabul Modeli'ni etkileyen bireysel, örgütsel ve sosyal faktörler oluşturulmuştur. Teknolojiye karşı tutumun teknoloji kullanma niyeti ve mevcut teknoloji kullanımı üzerindeki etkileri incelenmiştir. Teknolojiye karşı tutumu ve mevcut teknoloji kullanımını etkileyen davranışsal ve yönetimsel faktörler model kapsamında ele alınmıştır. Bununla birlikte hangi alanda dijital

Makale Geliş Tarihi: 9.5.2020 Makale Kabul Tarihi: 21.6.2020

1Sorumlu Yazar, Arş.Gör., İstanbul Üniversitesi İşletme Fakültesi, nevzatgungor@istanbul.edu.tr, http://orcid.org/00000001-9883-1985

${ }^{2}$ Arş.Gör.Dr., İstanbul Üniversitesi İşletme Fakültesi, cem.ozveren@istanbul.edu.tr://orcid.org/0000-0001-9435-6662

${ }^{3}$ Arş.Gör., İstanbul Üniversitesi İşletme Fakültesi, selcuk.yeke@istanbul.edu.tr, http://orcid.org/0000-0002-1953-6222 
dönüşümün gerçekleşmeye başladığını ortaya koyabilmek için muhasebe alanındaki yeni teknolojik gelişmeler araştırılmıştır. Sonuç olarak, bu çalışma doğrultusunda muhasebe alanında dijital dönüşüm gerçekleştirmek için çaba gösteren şirketlere yönelik kavramsal bir modelin sunulması amaçlanmıştır.

Anahtar Kelimeler: Dijital Dönüşüm, Teknoloji Kabul Modeli, Yeni Teknolojiler, Psikososyal Öncüller, Muhasebe Mesleği

\section{INTRODUCTION}

It is an undeniable fact that digitalization is now everywhere in our life. Based on this fact, the digitalization process is perceived differently for each institution, while some institutions turn this innovation into an opportunity, some institutions may resist this transformation process or encounter the resistance of employees, therefore, they can perform digitalization more slowly. It is evident that, no matter how late, digitalization is the inevitable end of any company in today's business world. Therefore, it is important to realize this change process with the least cost and the fastest way. In this article, how the companies go through the digitalization processes in their accounting departments, the impact of the company's corporate culture and other psychosocial factors such as senior management support on the digitalization process will be discussed and a model proposal will be presented within the scope of the Technology Acceptance Model (TAM).

When the historical background of the management area is analyzed, it is understood that the value of human increases with each passing time. Moreover, it is thought that human being considered as one of the inputs of production in the past is the most important resource today, and in the future, it will be used to value the word for the human in working life. Technological advances and the increasing availability of automation in business life have paved the way for people to take positions in where they will use their psycho-social skills and mental abilities by pulling them from relatively simple jobs that machines and software will do.

In recent years, the advancement of technology and digitalization has affected the business world, especially the accounting profession. Companies keeping up with these changes made their activities effective and productive and gained competitive advantage.

\section{EMERGING INFORMATION TECHNOLOGIES IN ACCOUNTING PROFESSION}

Information technologies enable the processes of recording, storing, processing and transforming data into information and transferring this information to relevant interest groups, and shortening and facilitating these processes. As the information is shared quickly and economically all over the world and the interaction is gradually increasing, businesses have started to carry out their activities completely or mostly in digital channels (Nagy et al., 2018).

Information technologies, which are highly preferred by individuals and organizations, are in continuous development and have become an important part of both social life and business world today. The developments in information technologies will lead to changes in the accounting profession (IFAC, 2017). With the developments in information technologies, it has become inevitable to adapt technologies such as artificial intelligence, blockchain, big data, cloud computing and internet of things, which contribute to the processes of producing, processing and storing financial information for the accounting profession.

Artificial intelligence, blockchain, cloud computing and internet of things, which are the most widely used technological tools that cause changes in the accounting profession, are described in this section. 
The Psychosocial Antecedents Of The Accounting Digital Transformation Of The Companies: A Model Proposal In Terms Of The Technology Acceptance Theory

\subsection{Artificial Intelligence in Accounting}

Artificial intelligence is the name given to computers equipped with capacities specific to human intelligence such as information acquisition, perception, vision, thinking and decision making (Perez et al., 2018). Artificial intelligence is widely used in businesses operating in different sectors today. For instance, astronomy, construction, agriculture, sports, education and healthcare so on (TİDE, 2017).

The benefits of artificial intelligence on accounting profession are summarized below (Boillet, 2018):

- Automatically recording accounting transactions.

- Fraud detection via machine learning

- Analyzing unstructured data

\subsection{Blockchain in Accounting}

Blockchain is an accounting technology. It is concerned with the transfer of ownership of assets, and maintaining a ledger of accurate financial information. But today it is used in various areas of activities by several sectors and firms. For example, currency, e-commerce, international payments, contracts, supply chain military etc. (Türkmen and Durbilmez, 2019, p.32).

The advantages of blockchain technologies to the accounting profession are presented below (Blasea, n.d.):

- Traceability, transparency and data loss prevention

- Automation

- Access / Availability

- Security

- Fast Payment

- Cost and Time Savings

\subsection{Cloud Computing in Accounting}

Today, countries like the United States, United Kingdom, Germany, Japan, South Korea and Turkey are making large investments to cloud computing. Microsoft, Google, Apple, Amazon and IBM etc. companies offer products and services to individuals and businesses. (Carey, 2020)

As in many other fields, cloud computing seems to be increasingly used in accounting profession. Cloud computing provides important advantages especially for firms and organizations in today's business world. The most prominent advantage of cloud computing is its great cost savings. In addition to lowering the operating costs, being useful and providing unlimited storage increases the use of cloud computing. The advantages of cloud computing for accounting profession are summarized below (Macquarrie, n.d.):

- Anytime, anywhere access

- Better security

- No installations or updates required

- Automatic backups

- No startup costs or long-term commitments

- Platform agnostic 


\subsection{Internet of Things (IoT) in Accounting}

The Internet of Things (IoT) is the communication network where objects or devices are connected with each other or with larger systems (Thibaud et. al., 2018, p. 79). As of 2018, there are approximately 22 billion devices connected to the internet around the Globe. Considering the increasing usage area and demand, the number of devices included in the internet in 2025 is expected to reach 39 billion, and in 2030 it is expected to reach 50 billion (Statista, n.d.).

With the IoT, it will be possible to control the stock status, warehouse entrances and exits, as well as the completeness and accuracy of physical material assets, without human factor. Moreover, with this emerging technology, accounting and auditing activities will be facilitated by decreasing cash payments and easier banking transactions. (ICAEW, 2019).

The main areas of usage of Internet of Things technology are summarized below: (Suresh et al. 2014, p. 6):

- Smart Environment

- Smart Building

- Supply Chain

- Agriculture

- Healthcare

- Security

- Logistic and Transportation

IoT could help improve accounting practices in a range of areas, including (ICAEW, 2019):

- data quality,

- transaction processing,

- asset, revenue, cost and risk analysis,

- product quality and

- employee performance

\section{TECHNOLOGY ACCEPTANCE MODEL (TAM)}

The Technology Acceptance Model (TAM) provides benefits to researchers and practitioners in the process of explaining human behavior at the point of whether individuals use technology or not (Davis, 1989). The origin of model comes from Fishbein and Ajzen (1975)'s The Theory of Reasoned Behavior (Madden, Ellen and Ajzen; 1992). Fishbein and Ajzen (1975) investigated whether the scales used to measure attitude and behavior in some studies by examining the research conducted on the attitude-behavior relationship. They found that the relationships were significant and reached the conclusion that attitudes should be evaluated in explaining the behavior. This theory is an important perspective for studies explaining attitude and behavior in the field of social psychology. In terms of this theory, attitude towards behavior and subjective normm effect the behavioral intention and behavioral intention effects behavior as shown in Figure 1. 


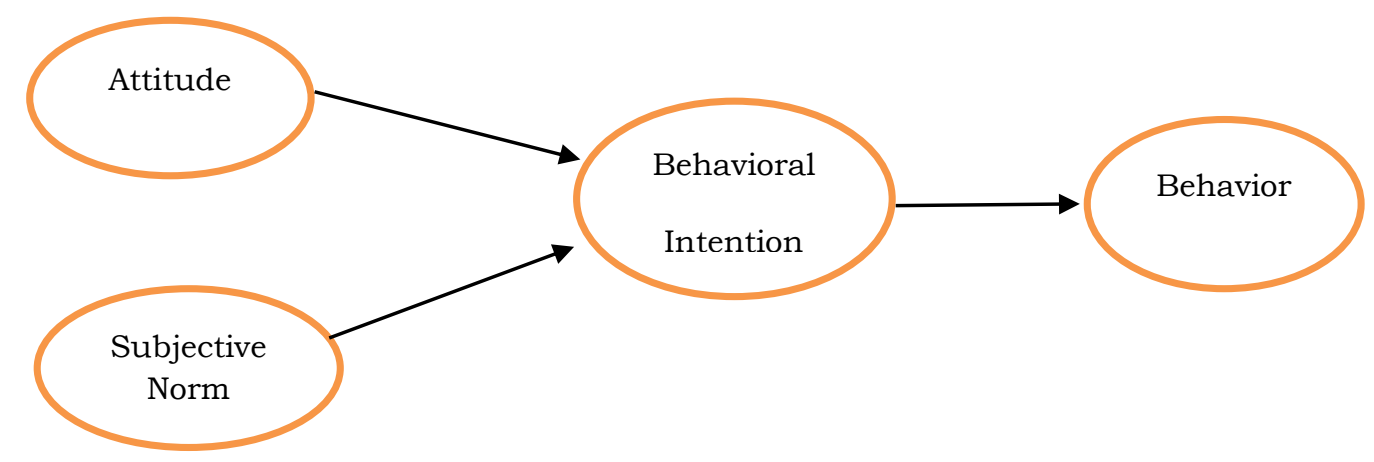

Figure 1.The Theory of Reasoned Behavior

Source: Fishbein, M., Ajzen, I. Belief, attitude, intention and behavior: An introduction to theory and research. Reading, Mass.: Addison-Wesley, 1975.

Ajzen and Fishbein (1977) stated that behavioral criteria in terms of observation includes four specific elements. That is,

- a given action is always performed with respect to

- a given target,

- in a given context, and

- at a given point in time

In terms of this theory, it is stated that human behavior is influenced by a number of factors. The determinant of the behavior is the intention of individuals regarding certain kinds of actions. In terms of the model, attitude towards behavior and subjective norms effect behavioral intention, this intention turns into behavior. Behavioral intention refers to the tendency of the person to do a certain behavior or not. Attitude about behavior defines the positive or negative evaluation of the person who will show the behavior against the realization of that behavior (Ajzen and Fishbein, 1980).

Subjective norms correspond to perceived social pressure in order to do or not do something. The opinion of whether individuals or groups that are important to the person to approve the behavior of the person is one of the determinants of the intention to do that behavior (Ajzen and Fishbein, 1980).

Ajzen and Fishbein (1980) stated The Theory of Planned Behavior as they extended Theory of Reasoned Action. In terms of this theory, perceived behavioral control is also an important factor for the intention to turn into behavior. Because the conditions of occurrence of behaviors and time may not be appropriate for this. In such cases, the necessity of Perceived behavior control has emerged. This shortcoming, seen in The Theory of Planned Action, was placed in the model as "Perceived Behavioral Control" in Theory of Planned Behavior (Kağıtçıbaşı, 1999) 


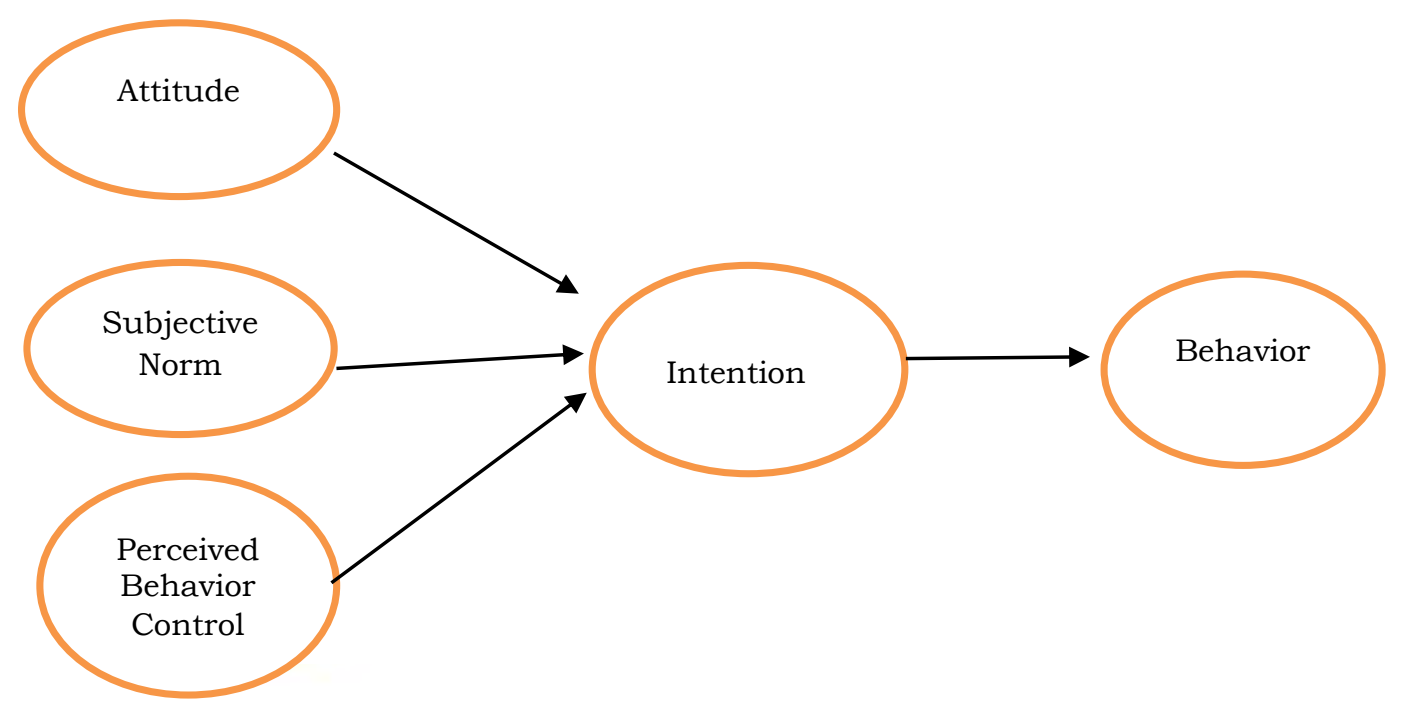

Figure 2. The Theory of Planned Behavior

Source: Ajzen, I. and Fishbein, M. (1980). Understanding Attitudes and Predicting Social Behavior New Jersey: PrenticeHall, Englewood Cliffs.

According to Theory of Planned Behavior as shown in Figure 2, the social behavior of people is under the control of certain factors and is caused by certain reasons and occurs in a planned way. Perceived behavioral control in the Theory of Planned Behavior was added to the Theory of Reasoned Action later, thus changing the name of the theory. Perceived behavioral control refers to how easy or difficult it is for a person to perform a behavior. It is the belief that the person is under his control to carry out the behavior in question. Attitude towards behavior refers to positive or negative evaluations about behavior. Subjective norms briefly explain what other people think about this behavior. These three factors define intention of the behavior. At the end of the study, this intention may turn in behavior or not (Sentosa and Mat, 2012).

When evaluated within the scope of both theories, if the individual's attitude towards behavior is positive, it is thought that this behavior will be evaluated positively by the reference circles, and if the control perception towards behavior is strong, the intention towards behavior will be stronger and the potential of intention to turn into behavior (Kağıtçıbaş1, 1999).

The usage of information system is vital for conforming today's business life. According to related literature, there are different factors affect the intention of using of information systems. Kijsanayotin et al. (2009) stated that usage of technology and user's acceptance are important factors that affect the intention of using information technologies. In terms of Taherdoost and Masrom (2009)'s study, ease of use, maintaining of control, usefulness and flexibility are another important factors.

The Technology Acceptance Model (TAM) developed by Davis (1986) based on the Theory of Reasoned Action (TRA) that argues that the use of technology is affected by the individual's attitude towards using technology, analyzes the individual's behaviors of accepting and using information technologies. (Venkatesh, Morris, G.B. Davis and F.D. Davis, 2003). In terms of the original form of this model, there are six variables as effect technology usage of people (Ma and Liu, 2004): 
The Psychosocial Antecedents Of The Accounting Digital Transformation Of The Companies: A Model Proposal In Terms Of The Technology Acceptance Theory

- system usage

- attitude toward use

- external variables

- perceived ease of use,

- perceived usefulness,

- behavioral intention to use

Davis (1989) carried out many of studies to validate perceived usefulness and perceived ease of use. At the end of these studies, he found that perceived ease of use can be considered as an antecedent of perceived usefulness.

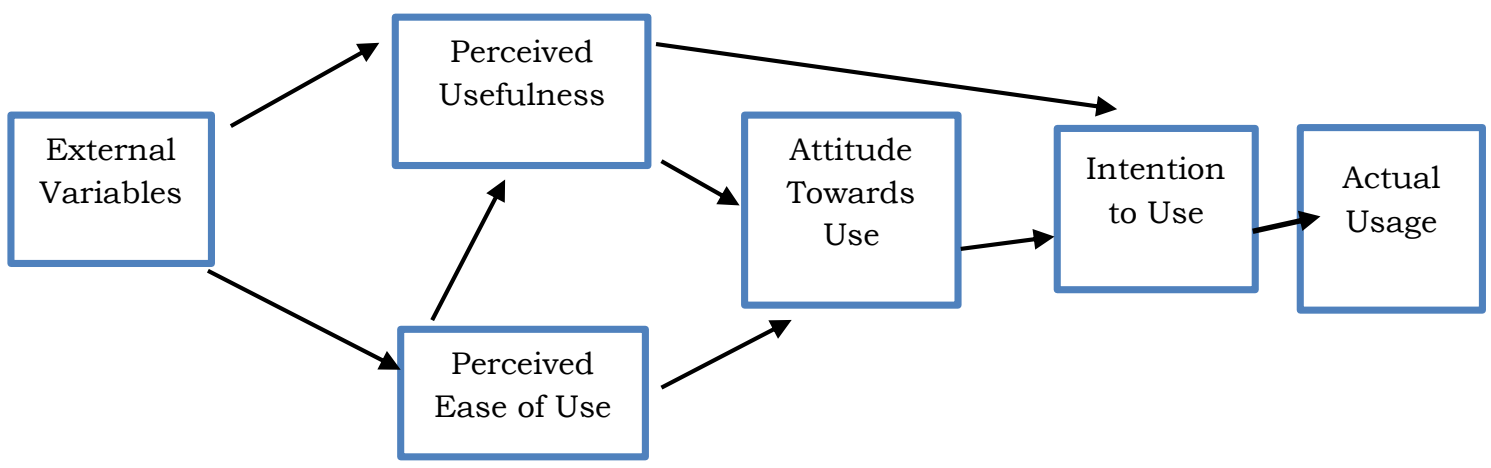

Figure 3. The Technology Acceptance Model

Source: Davis (1989) pp. 319-340.

According to the related model as shown in Figure 3, external variables, perceived usefulness and perceived ease of use effect attitude towards use of technology together. This attiude towards technology usage effects intention to use. At the end of the process, this intention may turn into behavior (this behavior refers to the usage of technology) or not (Davis, 1989).

\section{CULTURAL MANNERS IN TERMS OF TECHNOLOGY ACCEPTANCE MODEL}

In the related literature, there are some studies as analyzed the moderating effect of culture in Davis (1986)'s Technology Acceptance Model (Straub and Brenner, 1997; McCoy, Everard and Jones, 2005; Zakour, 2004). In terms of these studies, cultural effect was measured by using Hofstede (1980)'s cultural model and two or more countries were compared, so national culture's effect is used in these studies. While taking account these studies, country's uncertainty avoidance may be thought as an important factor effects technology usage of people (Lai, 2017). By this present study, the effect of organizational culture is analyzed.

Organizational culture consists of norms, interactions, activities, expectations, assumptions, beliefs, attitudes and values shared by members of the organization. One of the most important researchers in this field, E. Schein (1985) has defined organizational culture as the basic assumptions in a certain organization that a group created and developed to solve the problems of integration. According to Peters and Waterman (1995), organizational culture is defined as a structure consisting of dominant and shared values, reflected to the employees with symbolic meanings, slogans, consisting of stories, beliefs and fairy tales within the organization.

Although the concept of organizational climate is sometimes used in place of the concept of organizational culture in the relevant literature, organizational climate has a different meaning. Organizational climate defines a complex structure that includes an individual evaluations of the 
work environment (James and James, 1989; Neal and Griffin, 2000). The dominant definition of organizational climate in the related literature is employees' shared perception of organizational practices, events and procedures (Patterson et al., 2005).

The study carried out by McDermott and Stock (1999) shows that cultural characteristics as placed in Competing Values Model (Quinn and Kimberly, 1984) effect the advanced manufacturing technology implementation outcomes. In terms of this model, there are two dimensions (Denison and Spreitze, 1991):

- First dimension refers to the demands of flexibility and control.

- Second dimension refers to conflicting demands coming from environment and internal organization.

\begin{tabular}{|c|c|c|c|}
\hline & & & \\
\hline & GROUP CULTURE & $\begin{array}{l}\text { DEVELOPMENTAL } \\
\text { CULTURE }\end{array}$ & \\
\hline & Teamwork & Flexibility & \\
\hline & Participation & Growth & \\
\hline & Empowerment & Innovation & \\
\hline & Concern for ideas & Creativity & \\
\hline INTERNAL & & & EXTERNAL \\
\hline & Centralization & Task focus & \\
\hline & Control & Clarity & \\
\hline & Stability & Efficiency & \\
\hline & $\begin{array}{c}\text { Predictable outcomes } \\
\text { HIERARCHICAL } \\
\text { CULTURE }\end{array}$ & $\begin{array}{c}\text { Performance } \\
\text { RATIONAL } \\
\text { CULTURE }\end{array}$ & \\
\hline & & & \\
\hline
\end{tabular}

Figure 4. Ouinn and Kimberly's Competing Values Model

Source: Kimberly and Quinn (1984).

According to Quinn and Kimberly's model as shown in Figure 4, there are four different organizational culture types in terms of two dimensions as called flexibility \control and internal \external demands. For developmental cultures, they are more focus on external environmental demands and their processes are more flexible. At the end of the this mentality, innovation and creativity are the primary values for these cultures. Group cultures' processes are also flexible but these organizations are more related with internal demands. So, empowerment, teamwork and ideas are the main values in these organizations. For hierarchial cultures, they are more focus on internal demands and managerial control is the main tool for each process. For this reason; centralization, control and stability are important values. Rational cultures are also more sensitive to internal demands they carry out the related processes in flexible way. They are more task focus and efficiency in organization (Denison and Spreitze, 1991).

Another study implemented by Zammuta and O'Connor (1992) stated that flexible organizations are more successful in implementing of advanced manufacturing technology McDermott and Stock (1999). In terms of Competing Values Model, technology acceptance and implementation is considered high in more flexible organizations while comparing less flexible ones. According to Peters and Austin (1986), commercial innovation is more likely to be applied in decentralized organizations while comparing centralized organizations (Claver et al., 1998). According to longitudinal study carried out by Harper and Utley (2001): 
The Psychosocial Antecedents Of The Accounting Digital Transformation Of The Companies: A Model Proposal In Terms Of The Technology Acceptance Theory

Flexibility, team oriented work, autonomy, trust and sharing information freely is positively, predictability, compliance, carefulness, preciseness and rule orientation is negatively correlated with successful information technology implementation.

\section{MANAGERIAL ANTECEDENTS OF DIGITAL TRANSFORMATION}

Digital transformation means the combined effects of various digital innovations bringing about novel actors (and actor constellations), beliefs, values, structures and practices that alter, threat, relocate or consummate existing rules of the game within organizations and fields (Hinings et al., 2018 , pp.55). In addition to cultural and behavioral factors affecting the digital transformation in terms of The Technology Acceptance Model, also it is expected that managerial factors significantly affect the digitalization process of companies. The most important managerial factors can be leadership, organization structure and institutionalization along with cultural and behavioral factors to discuss digitalization process. While leadership is embraced as personal factor, organization structure and institutionalization are embraced as organizational factors which affect the digitalization process. Leadership attributes may be substantial factors whether digitalization starts or not. Organization structure and institutionalization are related with regulation of inter-organizational. Efficiency of organization structure and whether institutionalization is present or not may have influence on digitalization process (Sainger, 2018; Schwer and Hitz, 2018; Hinings et al., 2018).

Firstly, leadership is mentioned as a factor which influences on digitalization process. Leadership can be defined as the process of influencing and directing the activities of others to carry out personal and group goals under prescribed conditions. So leadership is a process related to what leader does. Within the frame of leadership definition, a leader plays an important role in influencing the others and inspiring to others, encouraging the others to behave throughout prescribed goals. Shortly, if there is a group that follow a person, the person is leader. Attributes, behavior and decision of business leader influence the group that follow the leader (Koçel, 2020, p.585). It is inevitable that organizations which undergo a digital transformation should have the appropriate leaders to maintain stability and secure successful results throughout the change and after the transformation is complete (Sow and Aborbie, 2018, p.143). Digital transformation is fundamentally about change which requires leadership because leadership is all about changes rather than stability. Leader plays important role for bringing and implementing all changes in the organization. Stakeholders also expect the same from leaders to take responsibility for organizational transformation. The successful transformation of an organization in this digital era commonly depends on how leaders of that organization accept and infuse work culture where digital technology is used as a tool for integrating information in real time rather than being solely dependent on technology. For example, Kodak's dropping from being the market leader was the result of leader's lack of foresight to understand change of customer expectation. The company paid attention to develop only digital technology which is one of strategic business unit without making necessary changes in its existing business model to inculcate these technologies or provisions to cope up with emerging digital market and changing customer requirements. The company's people, knowledge and infrastructure became obsolete and company failed to adopt to changes in the environment (Sainger, 2018, p.2).

In order to become absolutely digital, it is needed the vision which is established by both digital capabilities and leadership capabilities. It is mentioned that leadership capabilities in digital world involve a transformative vision of the organization's digital future, the achievement to participate every member of organization by influencing them about digitalization and the development of the competencies needed in the digitalization process (Larjovuori et al., 2016, p.1144). To get good 
outcomes at competition, leaders will be needed to adopt automation that is a tool of digitalization. Due to automation, companies can enable benefits such as quality, speed and efficiency. Automation represents both hope and challenge. Machines can take on work that is routine, dangerous, or dirty, and may allow us all to benefit our inherently human capabilities more entirely. Therefore it is pointed out that leaders will be prepared for a more automated forthcoming by revealing diverse skills, maximizing training and ensuring robust economic growth (Manyika et al., 2017, p.20).

Organizational structure is another factor that affect the digitalization process. Companies need to be able to adapt more quickly to more rapidly changing world. Companies realize to change arising from digital transformation and need a properly formed organization structure. Focusing and improving on functions of hierarchical organizations is not sufficient to succeed digital transformation. Hierarchically organizations have to allow for expanding span of control, being more creative and self-organizations. To achieve the acceleration needed in the digital world, a new organizational form can be formed. This organization form includes more decentralized management and more responsibility given to employees. This makes employees feel more motivated and deliver better results (Schwer and Hitz, 2018, p.10). This form is known as a living organism. A living organism that is a type of organization structure mobilizes quickly and empowers the employees. It evolves to thrive in an unpredictable, rapidly changing environment. A living organism has an agility that is an organizational competence. It is cited that agile organization has well-aligned and consistent IT interfaces, also well-maintained, easy-to-access and easy-to-navigate databases. Agile organization is able to integrate a range of emerging technologies with delivery practices into organization and company to build, implement and maintain these tools and interfaces (Kristensen and Shafiee, 2019, pp.4-9). Therefore, it can be commented that agile and not hierarchical organizations is open to digital transformation. It is thought that this organization has competency to complete digital transformation throughout functions of business (Verhoef et al., 2019, pp.5-8).

Digitalization is a process that forces top management to rethink some basic structures. Progress in technology causes that companies need to restructure their organizational structure, transform their departments, and develop new management models. Most of these changes begin as a result of new basic technologies that are essential for organizational renovation (Mežnar, 2018, p.349). These technologies provide greater information to employees. Owing to easy access to information, for any given decision they face employees will be better able to find out how their decision selections engage with the other decisions being made that are most closely related to their own area of work, how they relate to company objectives and targets, and how well their options align with industry practices. Furthermore, information technology can enable decentralized organization structure. It eases increased communication and coordination between decentralized decision makers and pivotal planners and upper management by producing information efficiency (Dewett and Jones, 2001, pp.328-329).

Another factor that affect the digitalization process is institutionalization. It is defined as a structure dominated by rules on communication and mutual influence in all matters. In other words, institutionalization can be defined as the fact that companies have a long-termed life without depending on people (Uzun, 2013, p.26). For example, ways of address and greet, reward and punishment methods, decision making styles, ways of establishing a dialogue with customers, etc. actions and behaviors may be institutionalized. Similarly, attitude of companies' founder towards employees may be related with institutionalization. Critic factor in here is that behaviors and actions become habitual by repeating. 
The Psychosocial Antecedents Of The Accounting Digital Transformation Of The Companies: A Model Proposal In Terms Of The Technology Acceptance Theory

Institutionalization in specially Turkey is perceived as managerial efforts which try to transform into organizations prioritizing continuity and moving away from centralized management perspective in executing of work and determining of responsibilities (Ulukan, 2005, pp.31-32). It is known that institutionalization is a basic argument of new institutional theory. New institutional theory reflects a school that pushes organizational rationality with its emphasis on institutions and symbols in organizational literature. According to new institutional theory, organizations have to consider social and environmental conditions rather than rational decisions to provide legitimacy and self-existence. Institutionalization and institutional isomorphism are an essential process to provide legitimacy and gain resource for organizations (Özcan, 2011, p.307). The institutionalization of a company implies occurring a system in the company. Therefore, it is required that companies have a structure that is based on professional management style. The founder of company has to give support to forming a structure that is unconnected from people so as to ensure institutional foundation in the company. Continuity of work is not based on a person. Even if person changes, a system has to be formed to continue work without disruption (Alayoğlu, 2003, p.65).

Institutionalization which states that there should be a model based on system rather than a person in companies, has some indicators about formation of institutionalization. These indicators are able to be explained as company constitution, professionalization, effective an organization structure, delegation, management insight, decision making style and effective a communication system (Yazıc1oğlu and Koç, 2009, p.500). Institutional work that is constituted in consideration of these indicators can help conceptualize transformation is put into practice by actors aiming at removing an established institution. For example, abolishing of traditional reporting involving high administrative burden and generating a new form of reporting that is based on various principles aiming at reducing the burden are type of institutional work (Troshani et al., 2018, p.18). In this direction, institutional work can be described as practices of individual and collective actors aiming at creating, maintaining, and disrupting institutions (Lawrence et al., 2011 , p.52). Institutional work includes creative and knowledgeable work of actors which may or may not achieve its desired ends and which interacts with existing social and technological structures in unintended and unexpected ways (Lawrence and Suddaby, 2006, p.219).

There are some novel institutional arrangements which are issue for digital transformation. These sorts are digital organizational formats, digital institutional platforms and digital institutional building blocks. From this viewpoint, an institutional perspective calls us to examine how these novel arrangements achieve social approval (i.e. legitimacy) in the eyes of critical stakeholders and their interaction with existing institutional arrangements. Institutionalization challenges and existing institutional arrangements are main arbiters in determine whether and how novel arrangements achieve acceptance (Hinings et al., 2018, pp.54-57). Institution, coordinating mechanisms of various types and existing institutional arrangements become essential to understanding value co-creation. It can be said that narrative of value co-creation develop into one of resource-integrating, mutual-service-providing actors, co-creating value through holistic, meaning-laden experiences in nested and matching up with service ecosystems. Value-creating actors are coordinated through institutions and institutional arrangements (Vargo and Lusch, 2016, p.7). It is thought that value-creating actors cannot make a decision about digital transformation without considering institutional arrangements. Because value-creating actors are be able to affect from institutional arrangements and act upon institutional arrangements. It can be said that digital transformation is issue at institutions which are reconstituted as co-create value (Akaka et al., 2017, pp.2-6). 


\section{METHODOLOGY}

\subsection{Goal of the Research}

In this study, it is aimed to determine antecedents of digital transformation in Turkish SMEs. Within this framework it is planned to propose a conceptual model in regards to antecedents of digital transformation. Conceptual model involves behavioral and managerial antecedents of digital transformation in the accounting profession. Organizational culture is handled as behavioral antecedent and leadership, organization structure and institutionalization are examined as managerial antecedents of digital transformation. However the leadership, organization structure and institutionalization that are not mentioned in The Technology Acceptance Model are also added to conceptual model and actions of companies towards digitalization in the accounting profession are discussed. Variables such as attitude towards technology and intention to technology in Technology Acceptance Model are explained within Theory of Planned Behavior. Therefore, it can be said that behavioral and managerial antecedents of digital transformation are based on theories which take part in literature.

\subsection{External Variables of the Model}

Subsidiary sources are used to determine antecedents of digital transformation. Especially databases, articles, journals and internet sources are benefited to gather data. Furthermore, significant relationships were formed in the model by obtaining prior researches about digital transformation.

This subsection reviews external variables of the model as determined. External variables of the model are:

- Organizational factors

- Social factors

- Individual factors.

\section{Organizational factors}

Igbaria et al. (1997) considered organizational factors as external variable. They categorized organizational factors as internal and external factors. The internal factors consist of internal support, internal training, and management support. The external factors comprise external (shareholder) support and external training. According to their research management support and external support have more impact on technology adoption than internal support and internal training in SME's. (Igbaria et al., 1997). Both have positive effects on technology acceptance through perceived usefulness and perceived ease of use (Igbaria et al., 1997). Thompson et al. (1991) did not find any significant effect of organizational factors on the PC usage and Venkatesh et al. (2003) found the direct effect of organizational factors on usage behavior, which is controlled by gender, age, experience and volunteering. Kim et al. (2009) found that organizational factors affected technology acceptance of internal auditors.

Based on Kim et al (2009) and other literature, organizational factors are determined as internal support, internal training and management support.

\section{Social factors}

Malhotra and Galletta (1999) investigate the importance of social factors in the Technology Acceptance Model. They obtained that identification and internalization had a positive effect on 
The Psychosocial Antecedents Of The Accounting Digital Transformation Of The Companies: A Model Proposal In Terms Of The Technology Acceptance Theory

technology usage. But, they determined that compliance had a weak negative effect on technology usage.

The effect of the subjective norm on technology acceptance led to contradictory results. Davis et al. (1989) stated that there was no significant relationship between social norms and usage. While Mathieson (1991) did not find a significant effect on the intention of the subjective norm, Taylor and Todd (1995) did find a significant effect on intention.

Venkatesh and Davis (2000) explained the impact of the social impact process (subjective norms, volunteering and image) on the acceptance of technology. The social impact process significantly affects technology adoption through perceived usefulness. Subjective norms are positively related to intention and are controlled by experience and volunteering, and are also negatively related to perceived usefulness and controlled by experience. They positively influence image and image positively affects perceived usefulness. (Venkatesh and Davis, 2000). According to Kim et al. (2009), social factors have no effect on internal auditors' technology acceptance.

Based on Kim et al (2009) and other literature, social factors are determined as internalization and corporate image.

\section{Individual Factors}

Individual factors are also used as cognitive factors (Venkatesh and Davis, 2000) and personal factors in Social Cognitive Theory (Compeau and Higgins, 1995). It has been shown that individual factors such as job relevance, output quality and demonstrability were important determinants of technology acceptance and affect technology acceptance through perceived usefulness (Venkatesh and Davis, 2000). Kim et al. (2009) found that individual factors have a significant impact on internal auditors' adoption of technology.

Based on Kim et al (2009) and other literature, individual factors are determined as job relevance, output quality and result demonstration.

\subsection{Model of The Research}

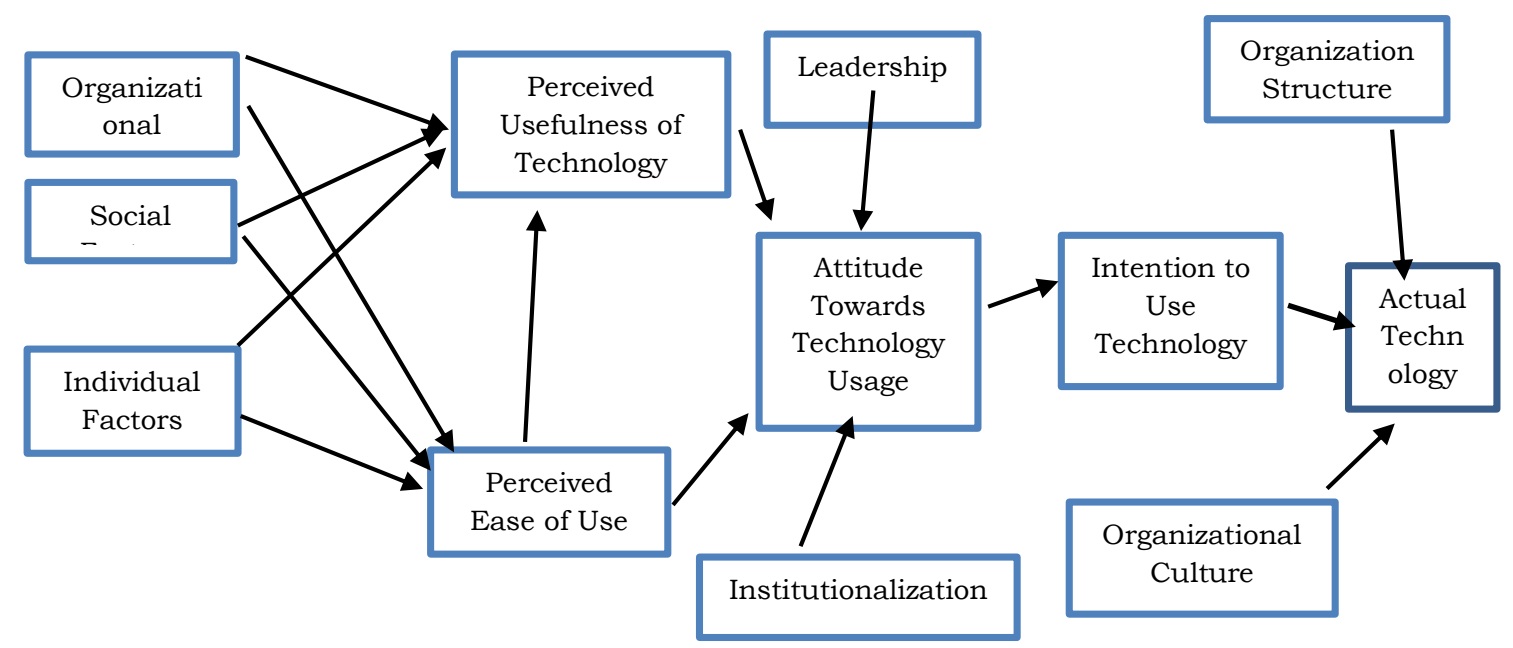

Figure 5. Model of the Research

In terms of the research model as shown in Figure 5, some organizational factors, social factors and individual factors effect perceived usefulness of technology. Perceived ease of use also effects perceived usefulness of technology. According to research model, both perceived ease of use and perceived usefulness of technology effects attitude towards technology usage together. Leadership 
style and institutionalization also effects this attitude towards technology usage. Attitude towards technology is the primary determinant of usage intention to use technology. As known from the social psychology literature, not every intention can be expected to turn into behavior. In this model, the intention to use technology can be turned into behavior to the extent that organizational structure and organizational culture allow, that is, the usage of technology in accounting transactions may increase.

\section{RESULTS}

In this study, it was formed a model proposal that is relation to antecedents of accounting digital transformation. Behavioral and managerial antecedents were presented to explain accounting digital transformation. But difference of this research rather than another studies about digital transformation is based on a theoretical background. It was propounded that technology acceptance model is key factor in the acceptance process of digital transformation. Particularly, technology acceptance and intention to use technology are influenced from attitude towards technology, subjective norm and perceived behavioral control. As attitude towards technology is significant factor in process intention to use technology, it is required to arise factors determining attitude towards technology. According to technology acceptance model, perceived usefulness and ease of use have effect on attitude towards technology. Fundamentally attitude towards technology, subjective norm and perceived behavioral control are behavioral base of intention to use technology. Passing from attitude to intention using technology is so crucial in beginning the accounting digital transformation. It is thought that beginning of accounting digital transformation depends on process passing from attitude to intention using technology. In this direction, based on technology acceptance model, attitude towards technology and intention to use technology are presented in conceptual model. Actually factors determining technology acceptance through perceived usefulness and ease of use are handled as organizational, social and individual. It is anticipated that an organization factor such as management support, social factors such as identification and corporate image and individual factor such as job relevance can be determinant in process of technology acceptance through perceived usefulness and ease of using technology.

Furthermore, it is thought that managerial antecedents can be key factors in occurring attitude towards technology and process of actual technology usage and attitude are related with internal dynamics of companies. Within the scope of the studies in the literature, it is anticipated the most important factors that have effect on attitude towards technology can be leadership and institutionalization. While leadership is an individual factor, institutionalization is related with corporate regulations. The both factors represents inside of companies in determining attitude towards technology. Nowadays, addition to traditional leadership theories, contemporary leadership approaches arise to manage effectively labor updating the demands from companies, business processes integrating environment and digitalization process. Therefore, leadership style is so crucial in the presence of positive or negative attitude towards technology. Institutionalization is shortly a system that arise from rules at company. The rules are constituted without depending to any person. For example, family companies are so far from institutionalization because of presence of company's founder. Company's founder is dominant power while decisions are made or new investment are discussed. It is no possible to generally say presence of institutionalization at family companies. While decision of company's founder is key to begin digitalization process, decision of top management at institutionalized companies are determinant for digitalization process. In this respect, it can be said that institutionalization has considerable effect on digitalization process. Organization structure that is last managerial 
The Psychosocial Antecedents Of The Accounting Digital Transformation Of The Companies: A Model Proposal In Terms Of The Technology Acceptance Theory

antecedent can influence the actual technology usage. It is required to accurately determine the organization structure for carrying out rapidly and effectively digitalization. Nowadays technological developments and innovations that closely influence the companies are too much. In addition to various environmental factors technologic environment of companies are too complex and have uncertainty. Organic and not hierarchical structures are favorable to reach knowledge, produce knowledge, follow the technological developments and actions of competitors, display proactive actions and use accurately technology.

\section{REFERENCES}

Ajzen, I., and Fishbein, M. (1977). Attitude-behavior relations: a theoretical analysis and review of empirical research. Psychological Bulletin, 84(5), 888.

Ajzen, I. and M. Fishbein: 1980, Understanding attitudes and predicting social behavior PrenticeHall, Englewood Cliffs, New Jersey.

Akaka, M.A., Vargo, S.L and Wieland, H. (2017). Extending the context of innovation: the cocreation and institutionalization of technology and markets. In Russo-Spena, T., Mele, $\mathrm{C}$ and Nuutinen, M. (Eds.) Innovating in Practice: Perspectives and Experiences, Springer, 43-57.

Alayoğlu, N. (2003). Aile şirketlerinde yönetim ve kurumsallaşma. Müsiad Yayınları, 3-157.

Blasea (n.d.). Blok zincirinin faydaları nelerdir?, Retrieved from: https://blasea.org/blockzincirinin-faydalari-nelerdir/

Boillet, J. (2018). The key issues boards need to consider when implementing artificial intelligence technology, Retrieved from: https://www.ey.com/en_us/assurance/why-ai-is-both-arisk-and-a-way-to-manage-risk

Claver, E., Llopis, J., Garcia, D., and Molina, H. (1998). Organizational culture for innovation and new technological behavior. The Journal of High Technology Management Research, 9(1), 55-68. Retrieved from: https://core.ac.uk/download/pdf/16355666.pdf

Carey S. (2020). AWS vs Azure vs Google Cloud: What's the best cloud platform for enterprise? Retrieved from: https://www.computerworld.com/article/3429365/aws-vs-azure-vsgoogle-whats-the-best-cloud-platform-for-enterprise.html

Compeau D.R. and Higgins C. A. (1995). Computer self-efficacy: development of a measure and initial test. MIS Quarterly,19(2), 189-211. doi: 10.2307/249688

Davis F.D., Bagozzi R.P. and Warshaw P.R. (1989) User acceptance of computer technology: a comparison of two theoretical models. Management Science, 35(8), 982-1002. doi: 10.1287/mnsc.35.8.982

Davis, F. D. (1989). Perceived usefulness, perceived ease of use and user acceptance of information technology. MIS Quarterly 13(3), 319-339. doi: 10.2307/249008

Denison, D. R., and Spreitzer, G. M. (1991). Organizational culture and organizational development: a competing values approach. Research in Organizational Change and Development, 5(1), 1-21.

Dewett, T and Jones, G. R. (2001). The role of information technology in the organization: a review, model, and assessment. Journal of Management, 27(3), 313-346. 
Fishbein, M., Ajzen, I. (1975). Belief, attitude, intention, and behavior: an introduction to theory and research. reading, MA: Addison-Wesley.

Harper, G. R., and Utley, D. R. (2001). Organizational culture and successful information technology implementation. Engineering Management Journal, 13(2), 11-15. doi: $10.1080 / 10429247.2001 .11415111$

Hinings, B., Gegenhuber, T and Greenwood, R. (2018). Digital innovation and transformation: an institutional perspective", Information and Organization, 28 (1), 52 - 61.

Hofstede, G. (1980). Motivation, leadership, and organization: do American theories apply abroad?. Organizational Dynamics, 9(1), 42-63. doi: 10.1016/0090-2616(80)90013-3

ICAEW. (2019). The internet of things and accounting: lessons from China. Retrieved from: https://www.icaew.com/technical/technology/data/internet-of-things-and-accounting

IFAC. (2017). Future of accounting profession: three major changes and implications for teaching and research. Retrieved from: https://www.ifac.org/knowledge-gateway/preparingfuture-ready-professionals/discussion/future-accounting-profession-three-majorchanges-and-implications-teaching-and-research

Igbaria M., Zinatelli N., Cragg P. and Cavaye A. (1997). Personal computing acceptance factors in small firms: a structural equation model. MIS Quarterly, 21(3), 279-302. doi: $10.2307 / 249498$

James, L. A., and James, L. R. (1989). Integrating work environment perspectives: explorations into the measurement of meaning. Journal of Applied Psychology, 74, 739-751

Kağıtçıbaşı, Ç. (1999). Yeni insan ve insanlar. İstanbul: Evrim Yayınevi, 326.

Kijsanayotin, B., Pannarunothai, S., and Speedie, S. M. (2009). Factors Influencing Health Information Technology Adoption in Thailand's Community Health Centers: Applying the UTAUT Model. International Journal of Medical Informatics, 78(6), 404-416. doi: 10.1016/j.ijmedinf.2008.12.005

Kim H.J., Mannino M. and Nieschwietz R.J. (2009). Information technology acceptance in the internal audit profession: Impact of technology features and complexity. International Journal of Accounting Information Systems, 10(4), 214-228 doi: 10.1016/j.accinf.2009.09.001

Kimberly, J. R., and Quinn, R. E. (1984). Managing organizational transitions. McGraw-Hill/Irwin.

Koçel, T. (2020). İşletme yöneticiliği: yönetim ve organizasyon, organizasyonlarda davranış, klasik, modern, çağdaş ve güncel yaklaşımlar, Beta, 1-759.

Kristensen, S. S and Shafiee, S. (2019). Rethinking organization design to enforce organizational agility, paper presented at 11th Symposium on Competence-Based Strategic Management, Stuttgart, 1-13.

Lai, P. C. (2017). The literature review of technology adoption models and theories for the novelty technology. JISTEM-Journal of Information Systems and Technology Management, 14(1), 21-38.

Larjovuori, R. L., Bordi, L., Mäkiniemi, J. P and Tammi, K. H. (2016). The role of leadership and employee well-being in organizational digitalization, 26th Annual RESER Conference, 1141-1154.

51 Hitit Üniversitesi Sosyal Bilimler Enstitüsü Dergisi - Y11 13 Sayı 1, 2020 
The Psychosocial Antecedents Of The Accounting Digital Transformation Of The Companies: A Model Proposal In Terms Of The Technology Acceptance Theory

Lawrence, T and Suddaby, R. (2006). Institutions and institutional work. In Steward R. Clegg, Cynthia Hardy., Thomas B. Lawrence and Walter R. Nord (Eds.) Sage Handbook of Organization Studies, Sage Publishing, 2nd Edition, 215-254.

Lawrence, T., Suddaby, R and Leca, B. (2011). Institutional work: refocusing institutional studies of organization. Journal of Management Inquiry, 20(1), 52-58.

Macquarrie, B. (n.d.). Are cloud accounting applications right for you and your clients?, Retrieved from: https://www.firmofthefuture.com/content/cloud-computing-benefits-and-risksof-cloud-accounting

Madden, T. J., Ellen, P. S., and Ajzen, I. (1992). A comparison of the theory of planned behavior and the theory of reasoned action. Personality and Social Psychology Bulletin, 18(1), 3-9.

Malhotra Y. and Galletta D.F. (1999). Extending the technology acceptance model to account for social influence: theoretical bases and empirical validation. Proceedings of the 32nd annual Hawaii international conference on system sciences, 1006.

Manyika, J., Lund, S., Chui, M., Bughin, J., Woetzel, J., Batra, P., Ko, R and Sanghvi, S. (2017) "Jobs lost, jobs gained: workforce transitions in a time of automation", McKinsey Global Institute Report, 1-148.

Mathieson K. (1991). Predicting user intentions: comparing the technology acceptance model with the theory of planned behavior. Information System Research, 2(3), 173-91.

McCoy, S., Everard, A., and Jones, B. M. (2005). An examination of the technology acceptance model in uruguay and the us: a focus on culture. Journal of Global Information Technology Management, 8(2), 27-45. doi: 10.1080/1097198X.2005.10856395

McDermott, C. M., and Stock, G. N. (1999). Organizational culture and advanced manufacturing technology implementation. Journal of Operations Management, 17(5), 521-533.

Mežnar, D. (2018). Restructuring the companies by implementing process of digitalization. Symorg, Doing Business in The Digital Age: Challenges, Approaches and Solutions, 348353.

Nagy, J., Oláh, J., Erdei, E., Máté, D., Popp, J. (2018). The role and impact of industry 4.0 and the internet of things on the business strategy of the value chain-the case of Hungary. Sustainability, 1-25.

Neal, A., Griffin, M. A., and Hart, P. M. (2000). The impact of organizational climate on safety climate and individual behavior. Safety Science, 34(1-3), 99-109.

Özcan, K. (2011). Kurumsal söylemin rasyonel temelleri: yeni kurumsal kuram bağlamında rasyonalite tartışması. Süleyman Demirel Üniversitesi Sosyal Bilimler Enstitüsü Dergisi, 13, 297-326.

Perez, J. A., Deligianni, F., Ravi, D., Yang, G.-Z. (2018). Artificial intelligence and robotics. Retrieved from: https://arxiv.org/ftp/arxiv/papers/1803/1803.10813.pdf.

Peters, T., and Waterman, R. (1982). In search of excellence. New York: Harper \& Row.

Sainger, G. (2018). Leadership in digital age: a study on the role of leader in this era of digital transformation. International Journal on Leadership, 6(1), 1-6.

Schein, E. H. (1985). Defining organizational culture. Classics of Organization Theory, 3(1), 490502. 
Schwer, K and Hitz, C. (2018). Designing organizational structure in the age of digitization. Journal of Eastern European and Central Asian Research, 5(1), 1-11.

Sentosa, I., and Mat, N. K. N. (2012). Examining a theory of planned behavior (tpb) and technology acceptance model (tam) in internet purchasing using structural equation modeling. Researchers World, 3(2 Part 2), 62.

Sow, M and Aborbie, S. (2018). Impact of leadership on digital transformation. Business and Economic Research, 8 (3), 139-148.

Statista (n.d.). Number of internet of things (IoT) connected devices worldwide in 2018, 2025 and 2030, Retrieved from: https://www.statista.com/statistics/802690/worldwideconnected-devices-by-access-technology/

Straub, D., Keil, M., and Brenner, W. (1997). Testing the technology acceptance model across cultures: a three country study. Information \& Management, 33(1), 1-11.

Suresh P., Daniel J. V., Parthasarathy V. and Aswathy R.H. (2014). A state of the art review on the Internet of Things (IoT) history, technology and fields of deployment, 2014 International Conference on Science Engineering and Management Research (ICSEMR), Chennai, 1-8. Retrieved from: https: / fardapaper.ir/mohavaha/uploads/2018/02/Fardapaper-A-state-of-the-artreview-on-the-Internet-of-Things-IoT-history-technology-and-fields-of-deployment.pdf

Taherdoost, H., and Masrom, M. (2009). An examination of smart card technology acceptance using adoption model. In Proceedings of the ITI 2009 31st International Conference on Information Technology Interfaces, 329-334.

Taylor S. and Todd P. (1995). Understanding information technology usage: a test of competing models. Information System Research, 6(2), 144-176.

Thibaud, M., Chi, H., Zhou, W., Piramuthu, S. (2018). Internet of things (IoT) in high-risk environment, health and safety (EHS) industries: a comprehensive review. Decision Support Systems, 108, 79-95.

Thompson R.L., Higgins C.A. and Howell J.M. (1991). Personal computing: toward a conceptual model of utilization. MIS Quarterly, 15(1), 125-43.

TİDE. (2017). Artificial-intelligence-part-I-revised. Retrieved from: www.tide.org.tr/file/documents / pdf/GPAI-Artificial-Intelligence-Part-I-Revised.pdf

Troshani, I., Janssen, M., Lymer, A and Parker, L. D. (2018). Digital transformation of businessto-government reporting: an institutional work perspective. International Journal of Accounting Information Systems, 31, 17-36.

Türkmen S.Y. and Durbilmez,S.E. (2019). Blockchain teknolojisi ve Türkiye finans sektöründeki durumu. Finans Ekonomi ve Sosyal Araştırmalar Dergisi (FESA), 4(1), 30-45.

Ulukan, C. (2005). Girişimcilerin ve profesyonel yöneticilerin kurumsallaşma perspektifi. Sosyal Bilimler Dergisi, 5(2), 29-42.

Uzun, E. (2013). Kahramanmaraş'ta faaliyet gösteren aile şirketlerinin kurumsallaşmaya bakış açıları ve stratejik öngörülerinde kurumsallaşmanın yeri. Kahramanmaraş Sütçü İmam University Social Sciences Institution, Doctoral Dissertation, 1-126. 
The Psychosocial Antecedents Of The Accounting Digital Transformation Of The Companies: A Model Proposal In Terms Of The Technology Acceptance Theory

Vargo, S. L and Lusch, R. F. (2016). Institutions and axioms: an extension and update of servicedominant logic. Journal of The Academy of Marketing Science, 44(1), 5-23.

Venkatesh V., Morris M.G., Davis G.B. and Davis FD. (2003). User acceptance of information technology: toward a unified view. MIS Quarterly, 27(3), 425-478. Retrieved from: https://experts.umn.edu/en/publications/user-acceptance-of-information-technologytoward-a-unified-view

Venkatesh, V. and Davis, F. D. (2000). A theoretical extension of the technology acceptance model: Four longitudinal field studies. Management Science, 46 (2), 186-204. doi: 10.1287/mnsc.46.2.186.11926

Verhoef, P.C., Broekhuizen, T., Bart, Y., Bhattaacharya, A., Dong, J.Q., Fabian, N and Haenlein, M. (2019) Digital transformation: a multidisciplinary reflection and research agenda. Journal of Business Research, Volume 2, 1-13.

Yazıcığlu, İ ve Koç, H. (2009). Aile işletmelerinin kurumsallaşma düzeylerinin belirlenmesine yönelik karşılaştırmalı bir araştırma. Selçuk Üniversitesi Sosyal Bilimler Enstitüsü Dergisi, 21, 497-507.

Zakour, A. B. (2004, February). Cultural differences and information technology acceptance. In Proceedings of the 7th annual conference of the Southern Association for Information Systems, 156-161.

Zammuto, R. F., and O'Connor, E. J. (1992). Gaining advanced manufacturing technologies' benefits: the roles of organization design and culture. Academy of Management Review, 17(4), 701-728. 


\section{GENIŞLETILMIŞ ÖZET}

$\mathrm{Bu}$ çalışmanın amacı küçük ölçekli firmaların muhasebesel dijital dönüşümlerinin öncül ve sonuçlarını alan yazında yer alan kuram ve yaklaşımlar özelinde incelemek ve kapsamlı bir model önerisinde bulunmaktır. Çalışmanın amacı çerçevesinde yeni teknolojilerin kabulünü ve entegrasyonunu açıklayan yaklaşımlar incelenmiş ve bu konuda gerek alan yazında, gerek ise uygulamada en çok kabul gören modellerden biri olan Teknoloji Kabul Modeli (Technology Acceptance Model) kullanılmış ve alan yazında yer alan çalışmalar baz alınarak modele birtakım yeni değişkenler eklenmiş ve bir model önerisinde bulunulmuştur.

Dijital dönüşümün her alan için bir zorunluluk olduğu yadsınamaz bir gerçektir. Büyük firmalar ve orta ölçekli firmaların hemen hemen hepsi yeni teknolojiyi bünyelerine entegre etme noktasında sorun yaşamamaktadırlar. Ancak ülkemizde de piyasada faaliyet gösteren şirketlerin yaklaşık yüzde doksanını oluşturan aile şirketleri için dijital dönüşüm adına ayrı bir parantez açmak gerekir. Aile şirketlerinin önemli bir kısmında kararlar daha çok kurucular ya da şirket sahipleri tarafından alınmakta, dolayısıyla verilen kararların ne kadar etkin olduğu noktasında birtakım soru işaretlerini de yanında getirmektedir. Söz gelimi gelişime görece daha kapalı bir şirket sahibinin yeni teknolojileri şirketine entegre etme fikrine kapalı olması olasıdır. Dolayısıyla dijital dönüşümün küçük ölçekli şirketlerde ve birtakım aile şirketlerinde sağlanmasına yönelik daha fazla çalışma yapılması gerekmektedir.

Teknoloji Kabul Modeli Ajzen ve Fishbein'in Planlanmış Davranış Kuramı üzerine inşa edilmiştir. $\mathrm{Bu}$ model kapsamında yeni teknolojinin kabul edilmesine yönelik birtakım faktörlerden bahsedilmiştir. Bu faktörler bireysel, sosyal ve örgütsel şeklinde sınıflandırılmıştır. Teknoloji Kabul Modeli özelinde ilgili faktörler karar vericilerin ve çalışanların teknolojinin kullanışl1lı̆̆ ve kullanım kolaylığına yönelik algısını etkileyecek olup sürecin devamımda bireylerin teknolojiyi kullanmaya yönelik niyetleri olumlu ya da olumsuz yönde etkilenecektir. Sosyal Psikoloji kuramlarından Ajzen ve Fishbein'in Planlanmış Davranışlar Kuramı ve diğer birtakım kuramların da altını çizdiği üzere her niyet davranışa yansımamaktadır. Niyetin davranışa dönüşmesini olumlu ya da olumsuz anlamda etkileyen, alan yazında da belirtilmiş birtakım faktörler bulunmaktadır. Kültür başta olmak üzere birtakım faktörler model özelinde ele alınmış ve yapılan çalışmalar referans gösterilerek modele eklenebileceği sonucuna ulaşılmıştır. Ayrıca Teknoloji Kabul Modeli'nde bahsi geçmeyen Liderlik, Örgüt yapısı ve kurumsallaşma değişkenleri de modele eklenerek şirketlerin muhasebe alanında dijitalleşmeye yönelik aldıkları aksiyonlar tartışılmıştır. Model alanda çalışan araştırmacılar ve uygulayıcılar için bir yol haritası çizme amacı gütmekte olup farklı bağlamlarda faaliyet gösteren küçük ölçekli şirketler için uygulamaya açıktır. 